\title{
Modification of character education into akhlaq education for the global community life
}

\author{
Imam Sutomo
}

State Institute for Islamic Studies Salatiga, Indonesia

E-mail:imam_sutomo@yahoo.co.id

\begin{abstract}
The term "character education" appears to be a massive movement around the world as a concern to rise up a generation of children who have strong moral character. All primary and secondary educational institutions socialize character education, including Indonesia since 2010. The Islamic world uses a specific term "akhlaq education". It has taken place throughout the history of Islamic civilization and has succeeded in cultivating Muslim characters. The core of akhlaq education is in the spiritual purification and obedience to God. Research from various Islamic countries show that the model of akhlaq education is not changed much. It is conserved from generation to generation, that make it far behind the sophistication of character education. Muslims seem not to put up with adequate characters to mingle with the global society. The implementation of akhlaq education let students comprehend a peaceful life only in their environment. Due to everyone's use of the Western science and technology, Muslims also adapt to this phenomenon and take a benefit to facilitate their needs. The format of character education as an instrument needs to be modified into akhlaq education, so that students are not locked into a narrow local insight and can take part in the life of the global community. This modification includes 1 ) adopting the content of character education for
\end{abstract}


the global community, 2) providing insights for the role of teachers and educational institutions, 3) variety of learning model, 4) involving parents and the community, and 5) accommodating students from various religions.

Istilah "pendidikan karakter" muncul menjadi gerakan masif di seluruh dunia sebagai bentuk kepedulian untuk menyiapkan anak didik berkarakter baik. Semua lembaga pendidikan dasar dan menengah menyosialisasikan pendidikan karakter, termasuk Indonesia mulai tahun 2010. Dunia Islam menggunakan term "pendidikan akhlaq" telah berlangsung sepanjang sejarah peradaban Islam dan telah berhasil dalam pembentukan karakter Muslim. Karakteristik pendidikan akhlaq terutama dalam penyucian rohani dan kepatuhan kepada Tuhan. Penelitian dari berbagai Negara Islam menunjukkan bahwa model pendidikan akhlaq tidak banyak perubahan, konservasi dari generasi ke generasi, jauh tertinggal dengan kecanggihan pendidikan karakter. Anak didik Muslim tidak disiapkan dengan karakter yang memadai untuk masuk dalam kehidupan masyarakat global. Seperti penggunaan ilmu dan teknologi Barat oleh semua orang (termasuk Muslim), format pendidikan karakter sebagai instrumen perlu diadaptasi dalam pendidikan akhlaq, agar anak didik tidak terbelenggu dalam wawasan lokal yang sempit dan dapat memasuki kehidupan masyarakat global. Adaptasi tersebut mencakup 1) content pendidikan karakter untuk masyarakat global, 2) wawasan guru dan peran lembaga pendidikan, 3) model pembelajaran yang variatif, 4) pelibatan orang tua dan masyarakat, dan 5) menampung siswa lintas agama.

Keywords: Character education; Akhlaq education; Global community; Curriculum

\section{Introduction}

Character Education is a popular topic in Indonesia's schools today. Character education is not a new idea; it is a call back to an oldest sacred mission in education. Modern education has produced many well-educated people in developing science and technology, but ignored the essence of the spiritual meaning of education. History of education that emphasizes character has long been omitted deliberately from educational 
activities, because it is even seen as something that is disturbing to the needs of modern society. The failure of the world of education in the form of school tragedies, such as shooting at schools in USA is an alarm for the scholars to reconsider the character education. ${ }^{1}$

Paradigm of Islamic education offers a conceptual framework regarding the ideal image of man. Islam has its own view on human and also has its own way to approach the human soul that is different from Western materialism's view. Each nation anthropologically has a unique understanding of human nature, Islam also provides a specific concept of man. Akhlaq (moral or character) is part of Islamic education which has its own teaching model to the students. Hassan writes, "it will be obvious that the Qur'an view of man differs from the secular humanistic or materialistic conceptions of man as envisaged by contemporary ideologies and isms."

Globalization is irreversible and inevitable the Muslims have no choice but to prepare and safeguard them to confront its onslaughts that come from all directions. Life in the global community requires citizens to promote peaceful coexistence between people with different religions, cultural backgrounds, and how the differences can be taken into account without creating conflict, discrimination, or exclusion. In the reality, violence, crime, drug abuse, war, and terrorism frighten people's lives in the world, even occurs in a one religious group. Some people questioned about the effectiveness of education that cannot lead the students to respect differences of race, ethnicity, religion, and others. In this case, how Muslims, based on their Islamic's faith, participate meaningfully with another people of the wider global community.

\footnotetext{
${ }^{1}$ Thomas Lickona, Educating for Character: How Our Schools Can Teach Respect and Responsibility, London: Batam Books, 1991, 6.

${ }^{2}$ M. Kamal Hassan, "Values Education Framework Based on Islamic Concepts and Precepts", Jurnal Pendidikan Islam, Vol. 2, No. 3 (December 1989), 71.
} 
The idea of character education obtains a positive response from the citizen of the world in the span of two decades. It seems to be a rapid development. While the Islamic world insists that akhlaq education needs to be reviewed on its learning practices which is obsolete. Muslims have a specific worldview in akhlaq education, but classical learning models should be revised to be relevant to the demands of the times. This study will explore about modification of character education into akhlaq education in order to provide new understanding for the students about the life in the global community.

\section{Character education}

There are some terminologies: character education, moral education, value education interchangeably and those are used as moral values education. Character is derived from a Greek word that means "to mark," as on an engraving. One's character is an indelible mark of consistency and predictability. It denotes enduring dispositional tendencies in behavior. It points to something deeply rooted in personality, to its organizing principle that integrates behavior, attitudes, and values. ${ }^{3}$ Berkowitz defines character as individual's set of psychological characteristics that affect that person's ability and inclination to function morally. Character is a complex constellation of psychological dimensions of a person. ${ }^{4}$ Characters are not stagnant, but can be changed for the better depending on the process that individuals interact with the environment. The process of character education is more difficult developing academic competence.

\footnotetext{
${ }^{3}$ Daniel K. Lapsley and Darcia Narvaez, Character Education, London: Praeger, 2005, 250.

${ }^{4}$ Marvin W. Berkowitz, "The Science of Character Education" in William Damon, Bringing in a New Era in Character Education, California: Hoover Institution Press Stanford University, 2002, 48-49.
} 
Character, as defined by Ryan and Bohlin (1999) consists of "knowing the good," "loving the good," and "doing the good."5 Character education is not about acquiring the right views currently accepted attitudes about ecology, prayer in school, gender, school uniforms, politics, or ideologically charged issues." ${ }^{6}$ In character education, the good is frequently summarized by a list of traits or virtues. The challenge for the community that has defined a set of desirable traits is to transmit to the next generation moral content, definitions, and the habit to engage in virtuous action. ${ }^{7}$ Dockery states, "developing the attitude, skills, and behaviors needed for productive life and positive citizenship may be more difficult to address in schools than developing academics."

Classical debate on whether the character could be taught or not, has been overlooked. Commitment on the idea that children should have a good character through school programs must be strengthened. Character education has become a national priority in all schools and the general public. Many schools and institutions have created a list of desired traits, with their very own terminology and definition. The program developed by the Heartwood Institute promotes seven virtues: respect, loyalty, honesty, love, justice, courage, and hope. William Bennett (1993) lists compassion, responsibility, honesty, friendship, work, courage, self-discipline, perseverance, loyalty, and faith. The Giraffe Heroes Program (Graham,

\footnotetext{
${ }^{5}$ Robert W. Howard, "Preparing Moral Educators in an Era Of Standards-Based Reform", Teacher Education Quarterly (Fall 2005), 50.

${ }^{6}$ Boston University, Character Education Manifesto, Boston: Center for the Advancement of Ethics and Character, 1996, 4.

${ }^{7}$ Robert W. Howard, "Preparing Moral Educators in an Era Of Standards-Based Reform”..., 50.

${ }^{8}$ Donna J. Dockery, "An Overview of Character Education and Recommendations for Implementation", in Patrice R. LeBlanc and Nancy Gallavan (eds.), Affective Teacher Education: Exploring Connections among Knowledge, Skills, and Dispositions, Rowman \& Littlefield Education, New York, 2009, 117.
} 
IJIMS, Indonesian Journal of Islam and Muslim Societies, Volume 4, Number 2, December 2014: 291-316

1999) emphasizes compassion and generosity. ${ }^{9}$ The Character Counts as one of the world's reputable organizations in promoting character education promotes the teaching of the Six Pillars of Character. ${ }^{10}$ In the context of Indonesian education, Minister of National Education develops 18 character values, ${ }^{11}$ and the Indonesia Heritage Foundation (IHF) disseminates an effective character-building education to schools and parents in order to inculcate the nine pillars of character. ${ }^{12}$

If we look at those character values comparatively, the table below (Table 1) shows the summary of those characters.

\section{Table 1}

\section{List of character values in comparison}

\begin{tabular}{|c|c|c|c|}
\hline Ministry of National & Indonesia Heritage & Character & $\mathrm{AICE}^{13}$ \\
\hline Education & Foundation & Counts & \\
\hline Religious & $\begin{array}{l}\text { Reverence and love towards } \\
\text { all God's Creation }\end{array}$ & Trustworthiness, & Be honest \\
\hline Honest & $\begin{array}{l}\text { Responsibility and Self- } \\
\text { Reliance (self-discipline and } \\
\text { orderliness) }\end{array}$ & Respect, & Be generous \\
\hline Tolerance & $\begin{array}{l}\text { Trustworthiness, Reliability, } \\
\text { and Honesty }\end{array}$ & Responsibility & Be just \\
\hline Discipline & Respect and Courtesy & Fairness & Live honorably \\
\hline Hard work & $\begin{array}{l}\text { Love, Caring, Empathy, } \\
\text { Charitable, and Team Work }\end{array}$ & Caring & Be kind \\
\hline Creative & $\begin{array}{l}\text { Confidence, Creativity, } \\
\text { Resourcefulness, Courage, } \\
\text { Determination, and } \\
\text { Enthusiasm }\end{array}$ & Citizenship & Be helpful \\
\hline
\end{tabular}

\footnotetext{
${ }^{9}$ Nel Noddings, Educating Moral People: A Caring Alternative to Character Education, New York: Teacher College Press Columbia University, 2002, 3.

${ }^{10} \mathrm{http}: / /$ www.charactercounts.org

${ }^{11}$ Said Hamid Hasan, "Pengembangan Pendidikan Budaya dan Karakter Bangsa", Bahan Pelatihan Penguatan Metodologi Pembelajaran Berdasarkan Nilai-Nilai Budaya untuk Membentuk Daya Saing dan Karakter Bangsa, Jakarta: Puskur Balitbang Kemendiknas, 2010, 9-10.

${ }^{12} \mathrm{http}: / /$ www.ihf.or.id/new/index.asp?lang=en

${ }^{13}$ The American Institute for Character Education (AICE), F. Clark Power et al. eds., Moral Education: A Handbook Two Volumes, America: Praeger, 2007, 18.
} 


\begin{tabular}{|c|c|c|}
\hline Independent & $\begin{array}{l}\text { Justice, Fairness, and } \\
\text { Leaderships }\end{array}$ & Have convictions \\
\hline Democratic & $\begin{array}{l}\text { Kindness, Friendliness, } \\
\text { Humility, and Modesty }\end{array}$ & Have courage \\
\hline Curiosity & $\begin{array}{l}\text { Tolerance, Flexibility, } \\
\text { Peacefulness, Unity }\end{array}$ & Be tolerant \\
\hline Sense of pride & & $\begin{array}{l}\text { Use talents } \\
\text { creditably }\end{array}$ \\
\hline Patriotism & & Provide security \\
\hline $\begin{array}{l}\text { Respect for } \\
\text { achievement }\end{array}$ & & $\begin{array}{l}\text { Understand } \\
\text { citizen obligations }\end{array}$ \\
\hline $\begin{array}{l}\text { Friendship / } \\
\text { communicative }\end{array}$ & & $\begin{array}{l}\text { Fulfill citizen } \\
\text { obligations }\end{array}$ \\
\hline Peace-loving & & $\begin{array}{l}\text { Stand for the } \\
\text { truth }\end{array}$ \\
\hline Fond of reading & & Defend freedom \\
\hline $\begin{array}{l}\text { Caring environm } \\
\text { Social care } \\
\text { Responsibility }\end{array}$ & & \\
\hline
\end{tabular}

In addition to the aforementioned character values, The Character Education Partnership (CEP), a coalition of organizations and individuals dedicated to helping schools develop moral and character education programs, propose some principles to the character education. Many school districts embrace some approaches to character education that are guided by those principles. Character Education Partnership (CEP) calls Eleven Principles of Effective Character Education;

1. Promotes core ethical values and supportive performance values as the foundation of good character.

2. Defines "character" comprehensively to include thinking, feeling, and behavior.

3. Uses a comprehensive, intentional, and proactive approach to character development.

4. Creates a caring school community.

5. Provides students with opportunities for moral action. 
6. Includes a meaningful and challenging academic curriculum that respects all learners, develops their character, and helps them to succeed.

7. Strives to foster students' self-motivation.

8. Engages the school staff as a learning and moral community that shares responsibility for character education and attempts to adhere to the same core values that guide the education of students.

9. Fosters shared moral leadership and long range support of the character education initiative.

10. Engages families and community members as partners in the characterbuilding effort.

11. Assesses the character of the school, the school staff's functioning as character educators, and the extent to which students manifest good character. ${ }^{14}$

Through the exposure on the characters values above, it is clear that the Indonesian Minister of National Education provides more detail descriptions (18 values), but it does not mention the value of freedom. In the context of preparing students for life in a global community, on the other hand, the four other institutions listed above insert other core values such as tolerant, democratic, and responsible though religious value is not explicitly mentioned. Character count and The American Institute for Character Education (AICE) do not explicitly mention the religious values as a choice of consistency to have schools stay away from religious activities. In contrast, Indonesian agencies are placing religious values as the first order.

Eleven Principles of Effective Character Education are signposts for teachers, parents, and communities in the implementation of character education. The guide books published by this institution provide some

\footnotetext{
${ }^{14}$ Tom Lickona, Eric Schaps, and Caherine Lewis, CEP's Eleven Principles of Effective Character Education, New York: Character Education Partnership, 2007, 1-4.
} 
very detailed descriptions on character instructions. Unfortunately, Islamic educational institutions in general do not have the moral teaching models in detail for each value. Modification of character education model is intended to make the akhlaq education richer in its varieties, fun, and interesting for students.

\section{Akhlaq education}

The word akhlaq is from Arabic (akhlāq أخلاق) and it shares the common semantic meaning with the English word character, temper, moral, morality (English), ${ }^{15}$ however, the word "akhlaq education" is a specific term in Islamic education. The epistemology of ethics/moral or character education recognizes the validity of reasoning. The word akhlaq refers to the source of the teachings of Islam that recognizes the truth of revelation. Set of values developed in akhlaq is to live harmony in horizontal communication between human beings and vertical communication with God (Khâliq or Creator). Simply saying, it is a good relationship between fellow human beings (makhlüq or creatures) and God. Moral, character, ethics are associated with the efforts to manage the interaction of individuals for the better communication in social life, while akhlaq is reviewing more details to the individual to take care spiritual purification (tazkiya al-nafs). In regard to this, Fatimah argues that "Islam stresses on the importance of self-purification by making it as an obligation upon each individual Muslim to seek knowledge and at the same time having good characters." 16

In accordance with the above idea of the scope of akhlaq education, Anderson, Tan, and Suleiman agree that "the formation of moral be-

\footnotetext{
${ }^{15}$ Hans Wehr, A Dictionary of Modern Written Arabic, ed., J. Milton Cowan, London: Otto Harrassowitz, 1971, 258.

${ }^{16}$ Fatimah Abdullah, "Teaching Islamic Ethics and Ethical Training: Benefiting from Emotional and Spiritual Intelligence", International Journal of Humanities and Social Science, Vol. 2 No. 3 (February 2012), 225.
} 
havior (known as tarbiya) is central to Islamic education. For some, it is not merely acquiring knowledge, but being morally transformed by it: for example, becoming more or excessive materialism, or acting in more ecologically aware ways. Others argued that the ethical aspect of education means questioning the usefulness of any knowledge. This implies that research should be designed around knowledge that is useful to humanity and avoids knowledge that is harmful. Others suggested that moral education (tarbiya) means cultivating the capacity in any situation to act in ways that are both practically effective and ethically correct - in other words, wisdom (hikma in Arabic). ${ }^{17}$

The most remarkable aspect of the Islamic system of education is the aim to instill higher values in the minds and hearts of the learners. ${ }^{18}$ Naturally, human beings love beauty, and always seek for beauty every time. Hassan says, beauty as a value refers to man's striving to achieve a good moral conduct - inner beauty - as well as a clean and delightful physical environment. To live in a locality where people posse praiseworthy character and interest with each other in a caring and considerate manner while taking great pains to make the cultural and physical environment beautiful, should be instilled in the minds of young Muslims to make the cultural and physical environment beautiful. ${ }^{19}$

The functional learning process requires engagement with the problems faced by children in daily activities. The design of instructional materials must be relevance to the world of the child so that the meaning and the message can be internalized in personal morals. The rules, regu-

\footnotetext{
${ }^{17}$ Paul Anderson, Charlene Tan, and Yasir Suleiman, Reforms in Islamic Education, Report of Conference Held at the Prince Alwaleed bin Talal Centre of Islamic Studies, University of Cambridge, (April 9-10, 2011), 6-7.

${ }^{18}$ Zafar Alam, Islamic Education Theory and Practice, New Delhi: Adam Publisher \& Distributor, 2003, 54.

${ }^{19}$ M. Kamal Hassan, "Values Education Framework Based on Islamic Concepts and Precepts”, Jurnal Pendidikan Islam, Vol. 2, No. 3 (December 1989), 77.
} 
lations and the characters that are considered relevant to children need to be described more operational and are adapted to the child's social environment. Character values such as respect, responsibility, sharing, perseverance, friendship, cooperation, self-discipline, and honesty have to be adjusted empirically to the students' world, the situation is actually encountered in a straightforward manner, not problems faced by teachers (adults). Learning will be more meaningful for the child if the materials are in accordance with the developmental stage of the reasoning as well as providing concrete examples of the child's life environment. Hashim and Langgulung suggest to reach cherish goals of Islamic education for the betterment of Islamic curricular reform in Muslim countries this way: "contents of education should be accompanied by appropriate teaching methods and meaningful to the children and relevant to their needs and their problems to Muslim world." ${ }^{20}$

\section{Global community}

In its wider sense, globalization provokes a world without boundaries. Mittelman (1997) wrote "globalization is a coalescence of varied transnational processes and domestic structures, allowing the economy, politics, culture, and ideology of one country to penetrate another." ${ }^{21} \mathrm{We}$ live in the global century, when national institutions and education systems can build their capacities to thrive by making connections with one another and other international actors. Globalization refers to all those processes by which the peoples of the world are incorporated into a single world society or global community or international society (Hedley Bull).

${ }^{20}$ Che Noraini Hashim and Hasan Langgulung, "Islamic Religious Curriculum in Muslim Countries: The Experiences of Indonesia and Malaysia," Bulletin of Education $\mathcal{E}$ Research, Vol. 30, No. 1 (June 2008), 16.

${ }^{21}$ Akira Iriye, Global Community: The Role of International Organizations in the Making of The Contemporary World, London: University of California Press, 2002, 196. 
The world's economy has become so highly interdependent, especially in financial markets. This interdependence is driven by science, technology and economics. Accordingly, Fay states "Global community engagement is dependent on established norms or conventions that assure all individuals and groups the rights to attributes such as mutual respect, social justice, freedom of expression, sanctity of historical and cultural knowledge and spaces, shared dignity and an esteemed wisdom." 22 Iriye ${ }^{23}$ defines global community as follow:

the building of transnational networks that are based upon a global consciousness, the idea that there is a wider world over and above separate states and national societies, and that individuals and groups, no matter where they are, share certain interests and concerns in that wider world. This consciousness has to be given some institutional form if it is to become effective-hence the role of international organizations.

Most Moslems have not fully realized that globalization has started. Razak suggests that "since the tidal waves of globalization have already started to touch the shores of Islamic countries, efforts need to be taken to prevent them from causing damage to their faith and Islamic way of life. ${ }^{24}$ Thus, the consequence of the awareness to prevent damage due to globalization according to Masud is that Muslims "....are critical of globalization and international organizations for the lack of ethical standards that could ensure equal opportunities for them also."25

\footnotetext{
${ }^{22}$ Fay Patel, Mingsheng Li, and Prahalad Sooknanan, Intercultural Communication: Building A Global Community, New Delhi: Sage, 2011, 51.

${ }^{23}$ Iriye, Akira, Global Community, 8.

${ }^{24}$ Mohd Abbas Abdul Razak, "Globalization and Its Impact on Education and Culture", World Journal of Islamic History and Civilization, 1 (1), (2011), 66.

${ }^{25}$ Muhammad Khalid Masud, "Muslim Perspectives on Global Ethics," in Sullivan, William M. and Kymlicka, Will, ed., The Globalization Of Ethics Religious and Secular Perspectives, New York: Cambridge University Press, 2007, 116.
} 
Islam is a religion of peace, but in reality Muslim communities show some contradictions. Islamic countries are always under turbulent conditions, unsafe, are heading even to ruin. Some Muslims think that this world was created by God only for them, so that anyone who did not agree with that thought is considered as the enemy. As what we find recently in the last five years, wars happened more frequently in Islamic countries than in non-Islamic countries. Muslims find it difficult to give a concrete example in building a peaceful society with other groups. Some Muslims still show the characters of warlike tribes than living in harmony to build the world together with other religions. Some Muslims feel they deserve the authority to rule this earth just for their own prosperity.

In this global community, Muslims are required to present theirselves as good citizens, so they can give positive impressions to other people. AlQur'an describes Muslims as ummatan wasathan (median community), ${ }^{26}$ they will be witnesses over the people. In a global community, Muslims are tested whether they can adapt to the environment and be the leader of the communities, become isolated, oppressed, or indeed act as a trouble makers.

\section{Imple mentation of akhlaq education: Pakistan, Tunisia, and Indonesia}

Stagnation of Islamic education in the long range spawned Muslim's generations to feel satisfied with their religiosity, though it did not reflect some excellent characters in building a peaceful life together with other religious groups. The progress of Western civilization alienates Muslims from the World's dynamic. The challenges for Islamic education reform, according to Rahman, is on "how it can become meaningful in the mod-

\footnotetext{
${ }^{26}$ Al-Qur'an surah Al-Baqarah [2] verse 143.
} 
ern intellectual and spiritual setting, not so much to save religion from modernity-which is, after all, only a partisan interest- but to save modern man from himself through religion." ${ }^{27}$

Pakistan and Tunisia are those Islamic countries that undoubtedly put religion in a very prominent position in the education systems. Indonesia, in this sense, is an exception; although in Indonesia Muslims are the majority. Pakistan was colonized by British, while Tunisia was colonized by French, and Indonesia was colonized by Dutch. These three countries having almost similar history as the occupied nations though have some very distinctive responses to the implementation of religious practices. Research in three countries is very interesting about the implementation of the akhlaq education in the context of the global community life. The process of implementation colored tension and conflict between the desire to form a good citizen and a devout religious followers.

In order to understand more fully the internal problem in Pakistan, Tunisia, and Indonesia, and the impacts of educational policies, the writer considered some findings of various researches performed by scholars in those three countries. First, in Pakistan, madrassas have evolved from the centers of Islamic learning. Madrassas have played an important role in shaping the spiritual thought of Muslims in Pakistan. Madrassas (Arabic: مدرسة, madrasah pl. مدارس, madāris) are for the elementary students. The mission of most Madrassas in Pakistan is to prepare students for religious duties. Adhering to strict religious teachings, madrassas teach Islamic subjects such as the Qur'an, Islamic law and Jurisprudence, Logic and the Prophet's traditions. The concentration of religious teachings increases depending on the level of the Madrassas (primary, middle or

\footnotetext{
${ }^{27}$ Fazlur Rahman, Islam and Modernity: Transformation of an Intellectual Tradition, Chicago: The University of Chicago Press, 1984, 140.
} 
high). ${ }^{28}$ The function of madrassa education has historically served a dual role in Pakistan, as it: 1) trains the next generation of Islamic scholars and clergy, and 2) often functions as a safety net for impoverished children or orphans by providing free room and board, along with religious education. ${ }^{29}$ Based on research about "educational policies of Pakistan since 1947-2009" Faizi, Shakil, and Akhtar concluded "in all educational policies there were so many recommendations given to make educational system according to Islamic values. ${ }^{30}$

Pakistan is reported to have some of the weakest education indicators globally. Pakistan's education system is regularly cited as one of the most serious impediments preventing the country from achieving its potential. The backwardness of madrassas is almost equal in Islamic countries, but in Pakistan (and Afghanistan) madrassas is associated with radical Islamist movement or terrorism. There are some semantic variations in the characterization of the madrassahs in Pakistan. But in the main, these media portrayed them as places where "jihadi ideology" -shorthand for anti-American, anti-Western, hateful, Islamist terrorism- was being imparted to the children. ${ }^{31}$ Some madrassas opposes Western-style secular education and rejects any effort to liberalise or modernise Islamic thought and practice. ${ }^{32}$ Candland says, "The real problem in these schools is that

${ }^{28}$ Uzma Anzar, "Islamic Education: A Brief History of Madrassas with Comments on Curricula and Current Pedagogical Practices", Paper for the University of Vermont, Environmental Programme, March 2003, 14.

${ }^{29}$ Sarah Ashraf, Religious Education and Training Provided by Madrassas in the AfghanistanPakistan Boundary Area, London: The Arts and Humanities Research Council (AHRC), 2012, 24.

${ }^{30}$ Waqar-un-Nisa Faizi, Anila Fatima Shakil, and Sajjad Hayat Akhtar, "Consideration of Islamic Values in the Educational Policies of Pakistan", Journal of Educational and Social Research, Vol. 2, (1) (January 2012), 298.

${ }^{31}$ Ali Riaz, Faithful Education: Madrassahs in South Asia, London: Rutgers University Press, 2008, 40.

${ }^{32}$ Sarah Ashraf, Religious Education and Training..., 11. 
students do not learn how to relate with other communities in a culturally diverse country and a globally interdependent world." ${ }^{33}$ Madrassa students tend to be less tolerant of non-Muslims, because religious education there does not provide a sufficient portion of the growth of tolerant behavior and cooperation for life in a global community, instead, give a higher priority to turn students into true faithful Muslim. The Pakistani madrasa curriculum remains virtually unchanged. The government blames madrasa authorities for the failure of its reforms. The ulama's opposition to these reforms was then used by the government to excuse its lack of commitment. Madrasa curriculum may be said to have played a role in creating an environment that encourages hostile or, at least, negative attitudes toward the "other." 34

Second, Tunisia is known as the Islamic state and Islam is at the root of the traditional system of values. The Tunisian school system was modeled on the French system and offered a uniform curriculum at each level in schools across the country. The implemented curriculum at school is compatible with the modern lives of the people. Children are introduced to learning materials related with the real lives of the communities, as it is revealed by Faour in his research report below.

The Tunisian experience in reforming school education, particularly the Islamic education curriculum, offers important lessons for the rest of the Arab world. Islamic education in Tunisian public schools aims to nurture tolerance and respect for other religions and Islamic sects, to promote the acceptance of Western democratic values as universal values that transcend national and regional boundaries, and to de-

\footnotetext{
${ }^{33}$ Christopher Candland, "Pakistan's Recent Experience in Reforming Islamic Education”, in Robert M. Hathaway, ed., Education Reform in Pakistan: Building for the Future, Washington: Woodrow Wilson International Center for Scholars, 2005, 162.

${ }^{34}$ Mumtaz Ahmad and Matthew J. Nelson, Islamic Education in Bangladesh and Pakistan: Trends in Tertiary Institutions, Washington: The National Bureau of Asian Research, 2009, 2.
} 
velop students' interest in analytical thinking on issues related to the meaning of religion and its role in life. These objectives are compatible with a modern, democratic conception of education for citizenship and are far more advanced in promoting democratic values and pluralism than those in Egypt. For that reason, one international study that analyzed the contents of school textbooks for several Arab countries praised the Tunisian education system as the model for all Arab states. ${ }^{35}$

Third, Indonesia is the largest Muslim-majority country in the world. Indonesia is not based on religious principles just like Pakistan and Tunisia, but Indonesia is not a secular nation either. The uniqueness of Indonesia may become an example of a moderate Islamic thought, where the plural community of different faiths can live together base on Pancasila principle. In contrast to Western countries, in Indonesia, religious education must be given to students from elementary school until university. Children of primary education have been introduced with central issues related with their being Moslem and their being citizens of Indonesia. Theoretically, children are not instilled with the dichotomy of obedience as a citizen or obedience as a Muslim.

Crucial problem of plural community is on how to keep the unity of the nation by showing tolerance towards different views. The implementation of religious education in Indonesia concerns much on the tolerance towards people of other religions. Current problems in its implementation often create conflicts between people of different religions because all religious believers need to stand for their faiths no matter how.

Studies on the implementation of akhlaq education in various educational institutions showed similarities in the viewpoint of the curriculum

${ }^{35}$ Muhammad Faour, Religious Education and Pluralism in Egypt and Tunisia, Washington: Carnegie Endowment for International Peace, 2012, 17. 
for primary and secondary education students. The students are introduced to reciting the Qur'an and ibadah (worship). The materials of akhlaq education were given to foster the spirit of religion.

\section{Modification characte r education into akhlaq education}

The development of Western science and technology is recognized as the highest achievement of the 21st century with the increasing number of innovations in various fields. Muslims shall not engage in its own world or become secret admirers of the glory of Islam in the past as nowadays, Western people, with their various weaknesses in term of spiritual, become very advanced in the field of science and technology development. In the context of the akhlaq education, we must admit some weaknesses of akhlaq education models. The adaptation will not interfere with the basic Islamic faith; it is indeed just an instrumental device to make joyful learning process for students. The writer proposes some modifications that can be done to improve the quality of akhlaq education in the following paragraphs.

\section{Adopting the content of character education for the global community}

The term character education is relatively new for practitioners of Islamic education. Though similar terms have previously been circulated such as moral education, value education, akhlaq education, ethics, and religious education, Islamic education practitioners question the difference between these six terminologies, and why character education is projected as a panacea to solve the problem with students' deviant behaviors.

Akhlaq education examines the human person more deeply, especially a spiritual purification in relation to God. Akhlaq education is likely to bring the child to get closer to God. Moral values such as ikhlas (sincere), ridla (contentment), qanaah (satisfaction), ta'dhim (aggrandizement), are the main components of akhlaq. Social values such as cooperation, tolerance, respect for 
others, or competitiveness are only effective for the internal environment of Muslims, but have not been widely applied in the wider society. There is still a very thick bulkhead blocking the interfaith relationships.

The materials of character education describe the real needs of students to support their living with others. Values such as citizenship, cooperation, tolerance, respect for the environment, loyalty, helpfulness and generosity are behavioral components that supports harmonious lives with others. Values such as kindness, cleanliness, compassion, cheerfulness, diligence, citizenship, joyfulness, self-control, courage, perseverance, punctuality are needed for shaping a mature personality.

Global community requires individual awareness about the diversity of cultural, ethnic, and religious who seek to live together without a sense of suspicion or hatred. Global community encourages an atmosphere based on the values of respect for others, tolerance, cooperation, and positive competition to achieve mutual benefit. Fay states "empathy and benevolence are other key attributes of engagement in a global community context, especially if individuals display an open and compassionate attitude, that foster goodness in each of us and global citizens.” ${ }^{36}$

\section{Providing insights for the role of teachers and educational institutions}

The main factor that determines the success of education is a teacher. If teachers have requirements and professional, the chances of students' success are higher. Curriculum and learning media serve only as supplements, while the teacher determines success of students. Therefore, an improving of insightful thoughts for the teacher should be prioritized. Insights on character education should be introduced to the teachers, so that teachers can distinguish the character from various perspectives.

\footnotetext{
${ }^{36}$ Fay Patel, Mingsheng Li, and Prahalad Sooknanan, Intercultural Communication: Building a Global Community, New Delhi: Sage, 2011, 51.
} 
The main factor that determines the success of education is the teachers. If all teachers comply with the requirements of being professional, the chances of students' success are higher. Curriculum and learning media play part only as supplements, while the teacher determines success of students. Therefore, an improving of insightful thoughts for the teacher should be prioritized. Insights on character education should be introduced to the teachers, so that teachers can distinguish various perspectives in teaching characters and choose the one fits method in their own school contexts.

The crucial problems in Islamic educational institutions are due to the facts that many teachers are weak in the mastery of teaching methods though undeniably they have high morality for the position of educators, as they are ikhlas (sincerity), sabar (patience), and compassionate for the students. Those teachers are still in services because schools need them regardless of their insufficient competences demanded by the teachinglearning processes. Changes in the mindset of the teachers are necessary to understand the complexities of characters. Teachers are highly recommended to upgrade their knowledge on pedagogy to prepare students to be able to live with dignity in the global community. Teachers of character education shall provide complete information about universal social values like honesty, hospitality, tolerance, responsibility that do not contradict the beliefs and traditions of other religions. Teachers must know the theme of teaching materials and how to teach accordingly to the level of the students cognitive, affective, and psychomotoric development. All efforts to improve the professionalism of the teachers depend much on the capacity of the educational institution, especially on the financial aspect.

\section{Variety of learning model}

Educational practices and research activities shall be interconnected to encourage new findings for the development of materials or methods of 
teaching. In line with this idea, Bill Puka, in reviewing character education programs, identifies six teaching methods. These are: a) instruction in basic values and virtues; b) behavioral codes established and enforced; c) telling stories with moral lessons; d) modeling desirable traits and values; e) holding up moral exemplars in history, literature, religion, and extolling their traits; f) providing in school and community outreach opportunities (service projects) through which students can exercise good traits and pursue good values. ${ }^{37}$

Limited time available for the teachers urge them to be highly selective in choosing the learning materials. Hence, it is difficult for religious teachers to walk alone to educate children without the support of other school subjects teachers. Teachers of other subjects should be able to provide the opportunity to include some messages of positive values in teaching. It becomes obligations for all teachers, regardless of the school subjects, to work together to create atmosphere conducive for directing students not to lose control of prescribed behaviors.

Learning should not be generalized because the child's holistic development of character is not determined by age. Grouping of children based on age commensurate many possibilities that they are differences in reasoning. Educational practices that pay less attention to individualized dimensions of the development of reasoning tends to homogenize with coercion. Cultural uniformity (conformity) in a mass school ignores the principle of individuality so that teachers no longer know the needs of the child. In this sense, it is necessary to restore education mission to serve children, to fulfill their rights of learning, and to create a climate where students' freedom of thinking is guaranteed.

${ }^{37}$ Bill Puka, "Inclusive Moral Education: a Critique and Integration of Competing Approaches", in M. Leicester, C. Modgil, and S. Modgil, Moral Education and Pluralism, London: Falmer Press, 1999, 114. 
Classical learning models rely on indoctrination of moral discourse. In community life and traditional homogeneous, this model appears to be effective, but no longer fits in a heterogeneous society. Character education and moral issues are more complex than other school subjects learning when seen from the benchmarks of success. The measurement of the success of character education is not just about the understanding of the knowledge of good character, but also the serious growth of consciousness in students' personalities.

The functional learning process requires engagement with the problems faced by children in daily activities. The design of instructional materials must be relevance to the world of the child so that the meaning and the message can be internalized in personal morals. The rules, regulations and the characters that are considered relevant to children need to be described more operational and are adapted to the child's social environment. Character values such as respect, responsibility, sharing, perseverance, friendship, cooperation, self-discipline, and honesty have to be adjusted empirically to the students' world, so that the situations described by the teachers are those actually encountered by students not those situations that create problems faced by the teachers (adults). Learning will be more meaningful for the child if the materials are in accordance with the developmental stage of the reasoning as well as providing concrete examples of the child's life environment. Hashim and Langgulung suggest that in order to reach cherish goals of Islamic education for the betterment of Islamic curricular reform in Muslim countries this way: "contents of education should be accompanied by appropriate teaching methods and meaningful to the children and relevant to their needs and their problems to Muslim world." 38

\footnotetext{
${ }^{38}$ Che Noraini Hashim and Hasan Langgulung, "Islamic Religious Curriculum in Muslim Countries: The Experiences of Indonesia and Malaysia"..., 16.
} 


\section{Involving parents and the community}

Akhlaq education needs a comprehensive approach, the involvement of the family and the community as the partners of the school, the creation of a positive moral culture in the school, and the intensive supports in the classroom. Theoretically to instill good character and growth of moral consciousness, it requires enough time for character and moral to grow gradually, not forcefully. Family takes some significant roles in the duration of the interaction between children and parents more than the schools may provide. Families (as children's first environment to know lives) should provide the moral foundations of social order to determine the personal rights and others who must be respected. Lickona says:

focusing on character in our families, schools, and communities will make a difference - has already made a difference - for those involved, if the effort becomes widespread enough, it will make a difference for our whole country and perhaps, to the extent that we become a better people, for the rest of the world. ${ }^{39}$

\section{Accommodating students from various religions}

Teachers apply character education to all students of any religion. There is no discrimination in the character education. It can be applied purely without instilling particular religious doctrines. However, in some cases, teachers may implement character education by giving examples of historical figures or literary works of a particular religion. Muslims often find it difficult to apply the meaning rahmatan $l i l$ ' $a>\mid a m i>n$ (benevolence for the universe) in the learning process. The question always arises on whether the teaching of Islam is applicable only for Muslims or for non-

\footnotetext{
${ }^{39}$ Thomas Lickona, Character Matters: How to Help Our Children Develop Good Judgment, Integrity, and Other Essential Virtues, London: Batam Books, 2004, 30.
} 
Muslims also? When Islam is from the very beginning aimed to save all people, then the akhlaq education must be communicated to every human being. Theological problems often become obstacles in the perspective of teachers to inculcate good virtues to others.

\section{Conclusion}

Based on the above explanation, it can be concluded that: character education today dominates the field of practice in moral education; it is now becoming a model in schools to prepare a good generations. The development of character education is compatible with the akhlaq education in order to prepare students to live peacefully in a global community. The adaptation will not interfere with the basic Islamic faith; therefore Muslims should be open for the possibility of the modification of character education into akhlaq education.

\section{Bibliography}

Abdullah, Fatimah, "Teaching Islamic Ethics and Ethical Training: Benefiting From Emotional And Spiritual Intelligence", International Journal of $\mathrm{Hu}$ manities and Social Science, Vol. 2 No. 3 (February 2012): 224-232.

Ahmad, Mumtaz and Nelson, Matthew J. Islamic Education in Bangladesh and Pakistan: Trends in Tertiary Institutions. Washington: The National Bureau of Asian Research, 2009.

Alam, Zafar. Islamic Education Theory and Practice. New Delhi: Adam Publisher \& Distributor, 2003.

Anderson, Paul, Tan, Charlene, and Suleiman, Yasir. Reforms in Islamic Education, Report of Conference Held at the Prince Alwaleed bin Talal Centre of Islamic Studies, University of Cambridge, April 9-10, 2011.

Anzar, Uzma, "Islamic Education: A Brief History of Madrassas with Comments on Curricula and Current Pedagogical Practices", Paper for the University of Vermont, Environmental Programme, March 2003. (Retrieved from: www.uvm.edu/ ${ }^{\sim}$ envprog/madrassah/madrassah-history.pdf)

Arthur, James. Education with Character: The Moral Economy of Schooling. London: Routledge Falmer, 2003.

Ashraf, Sarah, Religious Education and Training Provided by Madrassas in the Af- 
ghanistan-Pakistan Boundary Area, London: The Arts and Humanities Research Council (AHRC), 2012.

Berkowitz, Marvin W., "The Science of Character Education" in Damon, William, Bringing in a New Era in Character Education. California: Hoover Institution Press Stanford University, 2002: 43-63.

Bohlin, Karen E. Teaching Character Education Through Literature: Awakening the Moral Imagination in Secondary Classrooms. London: Routledge Falmer, 2005. Boston University. Character Education Manifesto. Boston: Center for the Advancement of Ethics and Character, 1996.

Choudhury, Masudul Alam. The Universal Paradigm and the Islamic World-System: Economy, Society, Ethics and Science. Singapore: World Scientific Publishing, 2008.

Dockery, Donna J., "An Overview of Character Education and Recommendations for Implementation", in Patrice R. LeBlanc and Nancy P. Gallavan eds., Affective Teacher Education: Exploring Connections Among Knowledge, Skills, and Dispositions. New York: Rowman \& Littlefield Education, 2009.

Faizi, Waqar-un-Nisa, Shakil, Anila Fatima, and Akhtar, Sajjad Hayat, "Consideration of Islamic Values in the Educational Policies of Pakistan", Journal of Educational and Social Research, Vol. 2, No. 1 (January 2012): 297-308.

Faour, Muhammad. Religious Education and Pluralism in Egypt and Tunisia. Washington: Carnegie Endowment for International Peace, 2012.

Masud, Muhammad Khalid, "Muslim Perspectives on Global Ethics," in Sullivan, William M. and Kymlicka, Will (eds.). The Globalization of Ethics Religious and Secular Perspectives. New York: Cambridge University Press, 2007: 93-116.

Hasan, Said Hamid, "Pengembangan Pendidikan Budaya dan Karakter Bangsa”, Bahan Pelatihan Penguatan Metodologi Pembelajaran Berdasarkan Nilai-Nilai Budaya untuk Membentuk Daya Saing dan Karakter Bangsa. Jakarta: Puskur Balitbang Kemendiknas, 2010.

Hassan, M. Kamal, "Values Education Framework Based on Islamic Concepts and Precepts", Jurnal Pendidikan Islam, Vol.2. No.3 (December 1989): 71 83.

Hashim, Che Noraini, and Langgulung, Hasan, "Islamic Religious Curriculum in Muslim Countries: The Experiences of Indonesia and Malaysia", Bulletin of Education $\mathcal{E}$ Research, Vol. 30, No. 1 (June 2008): 1-19.

Hathaway, Robert M. (ed.). Education Reform in Pakistan: Building for the Future. Washington: Woodrow Wilson International Center for Scholars, 2005. Hussain, Azhar, Salim, Ahmad, and Naveed, Arif. Connecting the Dots: Educa- 
IJIMS, Indonesian Journal of Islam and Muslim Societies, Volume 4, Number 2, December 2014: 291-316

tion and Religious Discrimination in Pakistan a Study of Public Schools and Madrassas. Washington: United States Commission on International Religious Freedom, 2011.

Iriye, Akira. Global Community: The Role of International Organizations in the Making of the Contemporary World. London: University of California Press, 2002. Lickona, Thomas. Character Matters: How to Help Our Children Develop Good Judgment, Integrity, and Other Essential Virtues. London: Batam Books, 2004.

Lickona, Thomas. Educating for Character: How Our Schools Can Teach Respect and Responsibility. London: Batam Books, 1991.

Nucci, Larry P. and Narvaez, Darcia. Handbook of Moral and Character Education. New York: Routledge, 2008.

Patel, Fay, Li, Mingsheng, and Sooknanan, Prahalad. Intercultural Communication: Building a Global Community. New Delhi: Sage, 2011.

Peterson, Christopher and Seligman, Martin E.P. Character Strengths and Virtues: A Handbook and Classification. New York: Oxford University Press, 2004.

Power, F. Clark (eds.). Moral Education: A Handbook. London: Praeger, 2008.

Puka, B., "Inclusive Moral Education: A Critique and Integration of Competing Approaches", in Leicester, M., Modgil, C., and Modgil, S. Moral Education and Pluralism. London: Falmer Press, 1999: 196-223.

Rahman, Fazlur. Islam and Modernity: Transformation of an Intellectual Tradition. Chicago: The University of Chicago Press, 1984.

Razak, Mohd Abbas Abdul, "Globalization and Its Impact on Education and Culture", World Journal of Islamic History and Civilization, vol. 1, no. 1 (2011): 59-69.

Riaz, Ali. Faithful Education: Madrassahs in South Asia. London: Rutgers University Press, 2008.

Suryadarma, Daniel, and Jones, Gavin W. (eds.). Education in Indonesia. Singapore: Institute of Southeast Asian Studies, 2013.

Wehr, Hans. A Dictionary of Modern Written Arabic, ed., J. Milton Cowan. London: Otto Harrassowitz, 1971.

Zuchdi, Darmiyati (ed.). Pendidikan Karakter dalam Perspektif Teori dan Praktik (Character Education in Theory and Practice Perspectives). Yogyakarta: UNY Press, 2011.

http://www.character.org

http://www.charactercounts.org

http://www.education-world.com

http://www.teachers.net

http://www.ihf.or.id/new/index.asp?lang=en 